\title{
PENGARUH SUHU EKSTRAKSI DAN KONSENTRASI ASAM SITRAT TERHADAP PIGMEN BETACYANIN DAUN KREMAH MERAH (A/ternanthera dentata) DAN APLIKASINYA PADA PANGAN
}

\author{
[The Effect of Extraction Temperature and The Concentration of Citric Acid Towards The Betacyanin \\ Pigment of Dentata Ruby Leaves (Alternanthera dentata) and The Application in Food]
}

\author{
Lisa Yusmita ${ }^{1{ }^{*}}$, Anwar Kasim²), dan Hazli Nurdin ${ }^{3)}$ \\ 1) Staf Pengajar Program Studi Teknologi Industri Pertanian, Universitas Dharma Andalas, Padang \\ 2) Staf Pengajar Program Studi Teknologi Hasil Pertanian, Universitas Andalas, Padang \\ ${ }^{3)}$ Staf Pengajar Program Studi Kimia, Universitas Andalas, Padang \\ *Email : lisa.y@unidha.ac.id / lisayusmita04@yahoo.com
}

Diterima 4 April 2017/ Disetujui 16 April 2017

\begin{abstract}
The aim of this research was to determine the best extraction temperature and concentration of citric acid in the extraction of betacyanin powder from Dentata Ruby leaves (Alternanthera dentata) and to know organoleptic panelist reception in the application of betacyanin pigment as a natural colourant to several food types. The design used in this research is Factorial Random Design (RAL) with 2 factors and 3 replications. The data obtained were analyzed statistically by $F$ test, then if significant effect was continued with HSD-Tukey test at $5 \%$ real level. The extraction temperature factor consisting of 2 levels ie cold temperature $\left(8^{\circ} \mathrm{C}\right)$ and room temperature $\left(25^{\circ} \mathrm{C}\right)$, and the citric acid concentration factor consisting of 4 levels ie $0 \%, 1 \%, 3 \%$ and $5 \%$. The results showed that the interaction between extraction temperature and citric acid concentration in the extraction process gave significantly different effect on betacyanin concentration, acidity degree $(\mathrm{pH})$, total acid and powder yield. The extract of betacyanin pigment powder extracted at room temperature $\left(25^{\circ} \mathrm{C}\right)$ with the addition of $0 \%$ citric acid was the best treatment with betacyanin concentration of $214.47 \mathrm{mg} / 100 \mathrm{~g}$ of material, $\mathrm{pH}$ 5.85 and total acid of $1.272 \%$ and powder yield of $56.43 \%$. The application of betacyanin powder extract on jelly, syrup and ice cream can be accepted organoleptically by the best treatment that is the addition at $1.5 \%$ concentration.
\end{abstract}

Key words: antioxidants, betacyanin, dentata ruby, colourant

\begin{abstract}
ABSTRAK
Penelitian ini bertujuan untuk menentukan suhu ekstraksi dan konsentrasi asam sitrat terbaik pada ekstraksi pigmen betacyanin daun kremah merah (Alternanthera dentata) dan mengetahui penerimaan panelis secara organoleptik terhadap aplikasi pigmen betacyanin sebagai pewarna alami terhadap beberapa jenis pangan. Rancangan yang digunakan dalam penelitian ini adalah Rancangan Acak Lengkap (RAL) faktorial dengan 2 faktor dan 3 kali ulangan. Data yang diperoleh dianalisa secara statistik dengan uji $F$, kemudian bila berpengaruh nyata dilanjutkan dengan uji HSD-Tukey pada taraf nyata $5 \%$. Faktor suhu ekstraksi yang terdiri dari 2 taraf yaitu suhu dingin $\left(8^{\circ} \mathrm{C}\right)$ dan suhu kamar $\left(25^{\circ} \mathrm{C}\right)$, sedangkan faktor konsentrasi asam sitrat yang terdiri dari 4 taraf yaitu $0 \%, 1 \%, 3 \%$ dan $5 \%$. Hasil penelitian menunjukkan interaksi antara suhu ekstraksi dan konsentrasi asam sitrat pada proses ekstraksi memberikan pengaruh yang berbeda nyata terhadap konsentrasi betacyanin, derajat keasaman $(\mathrm{pH})$ dan total asam serta rendemen bubuk. Ekstrak bubuk pigmen betacyanin yang diekstraksi pada suhu kamar $\left(25^{\circ} \mathrm{C}\right.$ ) dengan penambahan asam sitrat $0 \%$ merupakan perlakuan terbaik dengan karakteristik konsentrasi betacyanin sebesar 214,47 mg/100 g bahan, $\mathrm{pH} 5,85$ dan total asam 1,272 \% serta rendemen bubuk $56,43 \%$. Aplikasi penambahan ekstrak bubuk pigmen betacyanin pada jelly, sirup dan es krim dapat diterima secara organoleptik dengan perlakuan terbaik yaitu penambahan pada konsentrasi $1,5 \%$.
\end{abstract}

Kata kunci: antioksidan, betacyanin, kremah merah, pewarna.

\section{PENDAHULUAN}

Salah satu unsur yang dapat mempengaruhi kualitas sensoris pada makanan adalah warna. Pada pengolahan bahan makanan, pewarna sering ditambahkan untuk memperkuat warna asli makanan. Alam menghasilkan berbagai senyawa yang memadai untuk pewarna makanan, seperti antosianin, karotenoid, klorofil dan betalain. Tanaman kremah merah (Alternanthera dentata) merupakan jenis tanaman dari keluarga amaranthaceae yang mengandung betacyanin yang merupakan salah satu 
komponen betalain. Pigmen betalain belum banyak dieksplorasi sebagai senyawa bioaktif karena sumbernya yang sedikit di alam. Tetapi beberapa penelitian telah menunjukkan potensi senyawa ini sebagai antioksidan.

Menurut Jackman dan Smith (1996), penambahan larutan asam pada proses ekstraksi pigmen menyebabkan kerusakan membran sel tanaman dan secara simultan melarutkan pigmen tersebut. Sementara itu suhu ekstraksi mempengaruhi kelarutan bahan terekstrak dan mobilitas pelarut sehingga juga mempengaruhi jumlah pigmen yang terlarutkan.

Tujuan penelitian ini adalah untuk menentukan suhu ekstraksi dan konsentrasi asam sitrat terbaik pada ekstraksi pigmen betacyanin daun kremah merah (Alternanthera dentata) dan mengetahui penerimaan panelis secara organoleptik terhadap aplikasi pigmen betacyanin sebagai pewarna alami terhadap beberapa jenis pangan.

\section{BAHAN DAN METODE}

\section{Bahan dan Alat}

Bahan baku yang digunakan pada penelitian ini adalah daun Kremah Merah (Alternanthera dentata). Bahan yang digunakan untuk proses ekstraksi antara lain : aquadest, asam sitrat (konsentrasi asam sitrat dihitung berdasarkan jumlah pelarut), Bahanbahan untuk analisa kimia terdiri dari $\mathrm{HCl}$ pekat, $\mathrm{HCl} 6,76 \%$, fenolptalain, $\mathrm{NaOH} \mathrm{0,05} \mathrm{N}$, reagen luff, $\mathrm{KI} 20 \%, \mathrm{H}_{2} \mathrm{SO}_{4} 25 \%$, indikator amilum, indicator pp. Thio $0,1 \mathrm{~N}$, larutan buffer potassium klorida, larutan buffer sodium asetat, maltodekstrin dan bubuk es krim pondan rasa vanilla.

Alat-alat yang digunakan untuk penelitian antara lain: blender, termometer, erlenmeyer, gelas piala, alumunium foil, spray dryer, spektrofotometer, kuvet, oven, gelas ukur, penyaring vakum, kertas saring, $\mathrm{pH}$ meter, dan timbangan analitik, lemari pendingin.

\section{Rancangan Penelitian}

Dalam penelitian ini digunakan Rancangan Acak Lengkap (RAL) faktorial dengan 2 faktor dan 3 kali ulangan. Data yang diperoleh dianalisa secara statistik dengan uji $F$, kemudian bila berpengaruh nyata dilanjutkan dengan uji HSD-Tukey pada taraf nyata $5 \%$.

1. Faktor suhu ekstraksi yang terdiri dari 2 taraf yaitu :
A1 = suhu dingin $\left(8^{\circ} \mathrm{C}\right)$

$\mathrm{A} 2$ = suhu kamar $\left(25^{\circ} \mathrm{C}\right)$

2. Faktor konsentrasi asam sitrat yang terdiri dari 4 taraf :

$$
\begin{aligned}
& \text { B1 }=0 \% \\
& \text { B2 }=1 \% \\
& \text { B3 }=3 \% \\
& \text { B4 }=5 \%
\end{aligned}
$$

\section{Pelaksanaan Penelitian}

1. Persiapan Sampel

Daun Kremah merah (Alternanthera dentata) yang dipilih adalah daun yang berwarna merah keunguan dengan panjang daun sekitar 5-7 cm dan lebar 3-5 cm. Daun kremah merah (Alternanthera dentata) yang telah dipilih terlebih dahulu disortir dari kotoran. Kemudian setelah disortir dicuci bersih dan dikeringkan anginkan pada suhu ruang.

\section{Ekstraksi Betacyanin (Modifikasi Khuluq, 2007)}

Ekstraksi betacyanin berdasarkan pada penelitian Khuluq dkk, (2007) yang telah dimodifikasi dengan urutan sebagai berikut:

a. Daun kremah merah (Alternanthera dentate) sebanyak 100 gram dipotong kecil dan dimaserasi dengan pelarut aquadest sebanyak $300 \mathrm{ml}$ dan ditambahkan asam sitrat sesuai dengan perlakuan (persentase penambahan asam sitrat dihitung berdasarkan volume pelarut yang digunakan).

b. Kemudian dimaserasi sesuai perlakuan yaitu pada suhu dingin $\left(8^{\circ} \mathrm{C}\right)$ dan suhu kamar $\left(25^{\circ} \mathrm{C}\right)$ selama 12 jam.

c. Hasil ekstraksi disaring dengan menggunakan penyaring vakum.

d. Ampas dari hasil saringan kemudian dimaserasi lagi selama 12 jam sampai tidak ada lagi pigmen merah keunguan pada daun kremah merah (Alternanthera dentata).

e. Hasil ekstraksi kedua disaring dengan menggunakan penyaring vakum.

f. Ekstrak air kemudian dibubukkan dengan menggunakan spray dryer pada suhu 160 ${ }^{\circ} \mathrm{C}$ dengan penambahan maltodekstrin 20 $\%$ sehingga dihasilkan ekstrak bubuk pigmen betacyanin.

Ekstrak bubuk pigmen betacyanin diamati konsentrasi betacyanin, rendemen bubuk, $\mathrm{pH}$, dan total asam.

\section{Aplikasi pada Pangan}

Ekstrak bubuk pigmen betacyanin akan diaplikasikan terhadap pangan setelah dilakukan pengamatan terhadap konsentrasi 
betacyanin, rendemen bubuk, $\mathrm{pH}$, dan total asam. Ekstrak bubuk yang merupakan perlakuan terbaik (konsentrasi betacyanin tertinggi dan $\mathrm{pH}$ mendekati $\mathrm{pH}$ kestabilan betacyanin) akan diaplikasikan sebagai pewarna alami pada jelly, sirup dan es krim dengan berbagai tingkat konsentrasi penambahan bubuk ekstrak pigmen betacyanin daun kremah merah (Alternanthera dentate).

\section{Pengamatan}

Pengamatan yang dilakukan terhadap bahan baku adalah kadar air, total asam dan konsentrasi betacyanin. Pengamatan yang dilakukan terhadap bubuk ekstrak betacyanin adalah konsentrasi betacyanin, rendemen bubuk, derajat keasaman $(\mathrm{pH})$, dan total asam. Perlakuan terbaik berdasarkan pengamatan terhadap bubuk ekstrak betacyanin akanaplikasikan sebagai pewarna alami pada beberapa produk pangan dan dilakukan uji organoleptik meliputi uji kesukaan terhadap warna, aroma dan rasa.

\section{HASIL DAN PEMBAHASAN}

\section{Analisis Bahan Baku}

Winarno (2002) menyatakan bahwa dalam bahan makanan yang kering sekalipun seperti buah kering, tepung serta biji-bijian terkandung air dalam jumlah tertentu. Menurut Fardiaz (1992), keberadaan air dalam bahan makanan juga ikut menentukan terjadinya kerusakan dalam bahan makanan tersebut, karena air dapat dimanfaatkan oleh mikroorganisme untuk pertumbuhannya. Analisis bahan baku daun kremah merah (Alternanthera dentata) dapat dilihat pada Tabel 1.

Tabel 1. Analisis Bahan Baku Daun kremah Merah (Alternanthera dentata)

\begin{tabular}{lc}
\hline Komponen & Hasil * \\
\hline Kadar Air $(\%)$ & 84,6586 \\
Total Asam (\%) & 0,7182 \\
Konsentrasi Betacyanin & 265,6592 \\
(mg/100 g bahan) & \\
\hline
\end{tabular}

Keterangan : * hasil perhitungan kadar air dihitung berdasarkan berat basah daun kremah merah. Pada pengujian total asam sampel yang diuji yaitu daun kremah merah sedangkan untuk pengujian konsentrasi betacyanin sampel yang digunakan yaitu ekstrak air dari daun kremah merah yang telah dimaserasi.

Eder (1996) cit Khuluq et al. (2007) menyatakan bahwa betacyanin memiliki kelarutan yang tinggi dalam air sehingga ekstraksi biasanya dilakukan dengan pelarut air. Tingginya daya melarutkan betacyanin ini berhubungan dengan kepolaran pelarut yang mendekati tingkat kepolaran betacyanin sehingga meningkatkan kemampuan untuk melarutkan betacyanin tersebut dan ekstraksi dapat berjalan secara maksimal.

\section{Analisis Ekstrak Bubuk Pigmen Betacyanin dari Daun Kremah Merah Konsentrasi Betacyanin}

Rendahnyakonsentrasi betacyanin yang diperoleh dari bubuk pigmen yang diekstraksi pada suhu dingin $\left(8^{\circ} \mathrm{C}\right)$ disebabkan karena pada suhu dingin kelarutan bahan rendah akibatnya betacyanin tidak terekstrak secara sempurna. Menurut Khuluq et al. (2007), ekstraksi pada suhu kamar $\left(25^{\circ} \mathrm{C}\right)$ diperoleh konsentrasi betacyanin yang tinggi karena pada suhu tersebut memberikan mobilitas pelarut yang cukup baik pada waktu ekstraksi betacyanin dan tidak menurunkan stabilitasnya pada proses ekstraksi. Pengaruh suhu ekstraksi terhadap konsentrasi betacyanin bubuk pigmen betacyanin dari daun kremah merah dapat dilihat pada Tabel 2 .

Tabel 2. Pengaruh Suhu Ekstraksi Terhadap Konsentrasi Betacyanin Bubuk Pigmen Betacyanin dari Daun Kremah Merah

\begin{tabular}{lcc}
\hline \multicolumn{1}{c}{ Suhu Ekstraksi } & $\begin{array}{c}\text { Konsentrasi Betacyanin } \\
\text { (mg/100gekstrak bubuk) }\end{array}$ \\
\hline Suhu Kamar $\left(25^{\circ} \mathrm{C}\right)$ & $105,68 \mathrm{a}$ \\
Suhu Dingin $\left(8^{\circ} \mathrm{C}\right)$ & $79,15 \mathrm{~b}$ \\
\hline Keterangan : Angka-angka pada lajur yang sama yang \\
diikuti oleh huruf kecil yang sama menunjukkan berbeda \\
tidak nyata pada taraf $5 \%$.
\end{tabular}

Menurut Fennema (1996) dalam Khuluq et al. (2007), semakin tinggi suhu maka semakin meningkat energi kinetik dari suatu senyawa yang mengakibatkan mobilitasnya meningkat dan apabila kondisi tersebut dipertahankan maka semakin banyak pula jumlah betacyanin yang dapat diesktrak.

Rendahnya konsentrasi betacyanin yang didapatkan pada perlakuan yang ditambahkan asam sitrat dikarenakan adanya asam yang bersifat dapat mendegradasi betacyanin. Pengaruh konsentrasi asam sitrat terhadap konsentrasi betacyanin bubuk pigmen betacyanin dari daun kremah merah dapat dilihat pada Tabel 3.

Menurut Schwartz dan Von Elbe (1983) dalam Azeredo (2009) kondisi asam menyebabkan terjadinya rekondensasi dari 
asam betalamik dengan gugus amina dari penambahan residu dan pada $\mathrm{pH}$ rendah terjadi isomerisasi dan dehidrasi dari $\mathrm{C}_{15}$. Huang dan Von Elbe (1985) cit azeredo (2009) menguatkan pernyataan di atas dengan pendapat bahwa degradasi betacyanin dapat terjadi karena adanya panas atau asam yang dapat menyebabkan terjadinya isomerisasi, dekarboksilasi ataupun pembelahan yang berakibat terjadinya pengurangan warna merah ungu secara bertahap.

Tabel 3. Pengaruh Konsentrasi Asam Sitrat Terhadap Konsentrasi Betacyanin Bubuk Pigmen Betacyanin dari Daun Kremah Merah

\begin{tabular}{crc}
\hline $\begin{array}{c}\text { Konsentrasi } \\
\text { Asam }\end{array}$ & \multicolumn{2}{c}{$\begin{array}{c}\text { KonsentrasiBetacyanin } \\
\text { (mg/100g ekstrak bubuk) }\end{array}$} \\
\hline $0 \%$ & $170,97 \quad \mathrm{a}$ \\
$1 \%$ & $84,34 \quad \mathrm{~b}$ \\
$3 \%$ & $64,70 \quad \mathrm{C}$ \\
$5 \%$ & 49,64 & $\mathrm{~d}$ \\
\hline
\end{tabular}

Keterangan : Angka-angka pada lajur yang sama yang diikuti oleh huruf kecil yang sama menunjukkan berbeda tidak nyata pada taraf $5 \%$.

Berdasarkan penelitian Khuluq et al. (2007), yang melakukan riset ekstraksi dan stabilitas betacyanin daun darah (Alternanthera dentata) dengan kajian perbandingan pelarut air:etanol dan suhu ekstraksi diperoleh konsentrasi betacyanin antara $27,43 \mathrm{mg} / 100 \mathrm{~g}$ bahan sampai dengan $45,81 \mathrm{mg} / 100 \mathrm{~g}$ bahan. Ini berarti konsentrasi betacyanin yang dihasilkan pada penelitian ini lebih tinggi dibandingkan dengan yang didapatkan oleh Khuluq et al. (Tabel 4).

Tabel 4. Pengaruh Interaksi antara Suhu Ekstraksi dan Konsentrasi Asam Sitrat Terhadap Konsentrasi Betacyanin Bubuk Pigmen Betacyanin dari Daun Kremah Merah

\begin{tabular}{|c|c|c|c|}
\hline \multirow{2}{*}{$\begin{array}{c}\text { Suhu Ekstraksi } \\
\text { SuhuKamar }\left(25^{\circ} \mathrm{C}\right)\end{array}$} & \multirow{2}{*}{$\begin{array}{c}\begin{array}{c}\text { Konsen- } \\
\text { trasi } \\
\text { Asam }\end{array} \\
0 \%\end{array}$} & \multicolumn{2}{|c|}{$\begin{array}{c}\text { Konsentrasi } \\
\text { Betacyanin } \\
\text { (mg/100 g } \\
\text { ekstrakbubuk) }\end{array}$} \\
\hline & & 214,47 & $a$ \\
\hline Suhu Dingin $\left(8^{\circ} \mathrm{C}\right)$ & $0 \%$ & 127,48 & $b$ \\
\hline Suhu Kamar $\left(25^{\circ} \mathrm{C}\right)$ & $1 \%$ & 86,29 & C \\
\hline Suhu Dingin $\left(8^{\circ} \mathrm{C}\right)$ & $1 \%$ & 82,39 & C \\
\hline Suhu Kamar $\left(25^{\circ} \mathrm{C}\right)$ & $3 \%$ & 67,07 & $\mathrm{~d}$ \\
\hline Suhu Dingin $\left(8^{\circ} \mathrm{C}\right)$ & $3 \%$ & 62,33 & de \\
\hline Suhu Kamar $\left(25^{\circ} \mathrm{C}\right)$ & $5 \%$ & 54,87 & ef \\
\hline Suhu Dingin $\left(8^{\circ} \mathrm{C}\right)$ & $5 \%$ & 44,41 & $\mathrm{f}$ \\
\hline
\end{tabular}

Menurut Mastuti (2010), kandungan betacyanin total diberbagai tanaman Amaranthaceae berkisar antara 46 - 199 $\mathrm{mg} / 100 \mathrm{~g}$ bahan. Famili Amaranthaceae yang telah dibudidayakan mempunyai kandungan betacyanin yang lebih banyak dan memiliki biomassa jauh lebih tinggi dari pada spesies liarnya. Hal ini menunjukkan beberapa genotipe yang dibudidayakan sangat berpotensi untuk dikembangkan secara komersial sebagai sumber pewarna alami.

\section{Rendemen Bubuk}

Rendemen bubuk tertinggi diperoleh pada ekstrak dengan konsentrasi penambahan asam sitrat terbesar (5\%) sedangkan rendemen bubuk terendah diperoleh dari ekstrak dengan konsentrasi penambahan asam sitrat terkecil. Jadi tingginya rendemen bubuk yang dihasilkan berbanding lurus dengan tingginya konsentrasi asam sitrat yang ditambahkan. Pengaruh suhu ekstraksi, konsentrasi asam sitrat dan interaksi antara suhu ekstraksi dan konsentrasi asam sitrat terhadap rendemen bubuk pigmen betacyanin dari daun kremah merah masing-masing dapat dilihat pada Tabel 5, Tabel 6, dan Tabel 7.

Selain konsentrasi asam sitrat, tinggi rendahnya rendemen bubuk juga dipengaruhi oleh proses spray drying. Pada saat pengeringan, sebagian kecil ekstrak bubuk melekat pada tabung dan pada wadah penampung. Hal ini tentu saja dapat mengurangi rendemen bubuk produk yang dihasilkan.

Tabel 5. Pengaruh Suhu Ekstraksi Terhadap Rendemen Bubuk Pigmen

Betacyanin dari Daun Kremah Merah

\begin{tabular}{|c|c|}
\hline Suhu Ekstraksi & Rendemen Bubuk (\%) \\
\hline Suhu Dingin $\left(8^{\circ} \mathrm{C}\right)$ & 47,520 \\
\hline Suhu Kamar $\left(25^{\circ} \mathrm{C}\right)$ & 46,204 \\
\hline \multicolumn{2}{|c|}{$\begin{array}{l}\text { Keterangan : Angka-angka pada lajur yang sama yang } \\
\text { diikuti oleh huruf kecil yang samamenunjukkan berbeda } \\
\text { tidak nyata pada taraf } 5 \% \text {. }\end{array}$} \\
\hline \multicolumn{2}{|c|}{$\begin{array}{l}\text { Tabel 6. Pengaruh Konsentrasi Asam Sitrat } \\
\text { Terhadap Rendemen Bubuk Pigmen } \\
\text { Betacyanin dari Daun Kremah Merah }\end{array}$} \\
\hline KonsentrasiAsam & Rendemen Bubuk(\%) \\
\hline $5 \%$ & $56,173 a$ \\
\hline $3 \%$ & 50,881 \\
\hline $1 \%$ & 41,322 \\
\hline $0 \%$ & 39,072 \\
\hline
\end{tabular}

Keterangan : Angka-angka pada lajur yang sama yang diikuti oleh huruf kecil yang sama menunjukkan berbeda tidak nyata pada taraf $5 \%$. 
Tabel 7. Pengaruh Interaksi antara Suhu Ekstraksi dan Konsentrasi Asam Sitrat Terhadap Rendemen Bubuk Pigmen Betacyanin Daun Kremah Merah

\begin{tabular}{lcll}
\hline Suhu Ekstraksi & $\begin{array}{c}\text { Konsentrasi } \\
\text { Asam }\end{array}$ & $\begin{array}{l}\text { Rendemen } \\
\text { Bubuk (\%) }\end{array}$ \\
\hline SuhuKamar $\left(25^{\circ} \mathrm{C}\right)$ & $5 \%$ & 56,433 & $\mathrm{a}$ \\
Suhu Dingin $\left(8^{\circ} \mathrm{C}\right)$ & $5 \%$ & $55,914 \mathrm{ab}$ \\
Suhu Dingin $\left(8^{\circ} \mathrm{C}\right)$ & $3 \%$ & 51,363 & $\mathrm{ab}$ \\
Suhu Kamar $\left(25^{\circ} \mathrm{C}\right)$ & $3 \%$ & 50,399 & $\mathrm{~b}$ \\
Suhu Dingin $\left(8^{\circ} \mathrm{C}\right)$ & $1 \%$ & 43,553 & $\mathrm{C}$ \\
Suhu Dingin $\left(8^{\circ} \mathrm{C}\right)$ & $0 \%$ & 39,250 & $\mathrm{C}$ \\
Suhu Kamar $\left(25^{\circ} \mathrm{C}\right)$ & $1 \%$ & 39,091 & $\mathrm{C}$ \\
Suhu Kamar $\left(25^{\circ} \mathrm{C}\right)$ & $0 \%$ & 38,894 & $\mathrm{C}$ \\
\hline
\end{tabular}

Keterangan : Angka-angka pada lajur yang sama yang diikuti oleh huruf kecil yang sama menunjukkan berbeda tidak nyata pada taraf $5 \%$.

\section{pH}

Berdasarkan Tabel 10 dapat diketahui bahwa nilai $\mathrm{pH}$ tertinggi yaitu 5,8467 diperoleh pada ekstrak bubuk pigmen betacyanin yang dimaserasi pada suhu kamar $\left(25^{\circ} \mathrm{C}\right)$ tanpa penambahan asam sitrat (konsentrasi $0 \%$ ). Nilai $\mathrm{pH}$ yang didapat pada perlakuan tersebut mendekati netral karena penggunaan pelarut air tanpa penambahan asam sitrat. Hal ini sesuai dengan pendapat Sastrohamidjojo (2005) cit Saati (2010) yang menyatakan bahwa air merupakan larutan netral yang dapat melarutkan pigmen dan senyawa cita rasa lainnya yang mempunyai nilai $\mathrm{pH} 7$ atau dalam kondisi netral. Nilai $\mathrm{pH}$ ekstrak sangat dipengaruhi oleh pelarut yang digunakan sewaktu ekstraksi. Sukardjo (1997) cit Saati (2010) menjelaskan bahwa apabila konsentrasi ion $\mathrm{H}+$ lebih besar dari pada ion $\mathrm{OH}-$ maka larutan akan bersifat asam dan apabila konsentrasi ion $\mathrm{H}+$ lebih kecil dari pada ion $\mathrm{OH}$ - maka larutan akan bersifat basa. Nilai $\mathrm{pH}$ yang rendah yaitu berkisar dari 1,8500 2,7667 diperoleh pada ekstrak bubuk pigmen betacyaninyang dimaserasi menggunakan pelarut air yang ditambahkan asam sitrat pada konsentrasi 1\%, 3\% dan 5\%. Menurut Anonim (2011) asam sitrat mampu menurunkan pH larutan karena adanya kandungan asam yang berasal dari tiga gugus karboksil $\mathrm{COOH}$ yang dapat melepaskan proton ke dalam larutan. Saati (2010) menambahkan bahwa adanya proses evaporasi pada ekstrak menyebabkan berkurangnya air pada bahan sehingga dapat meningkatkan konsentrasi asam sehingga memicu adanya penurunan $\mathrm{pH}$.

Menurut jackman dan Smith (1996), betalain relatif stabil dalam kisaran $\mathrm{pH}$ yang luas yaitu sekitar 3 sampai 7 yang memungkinkan aplikasinya pada makanan yang bersifat asam. Di bawah $\mathrm{pH}$ 3,5 penyerapan maksimum bergeser pada panjang gelombang yang lebih rendah dan di atas $\mathrm{pH} 7$ penyerapan maksimum bergeser pada panjnag gelombang yang lebih tinggi. Di luar kisaran $\mathrm{pH} 3,5-7$ intensitas dari spektrum tampak mengalami penurunan. Reid et al.,(1980) menambahkan bahwa kerusakan betacyanin meningkat tajam di bawah $\mathrm{pH} 4$.

Tabel 8. Pengaruh Suhu Ekstraksi Terhadap $\mathrm{pH}$ Ekstrak Bubuk Pigmen Betacyanin dari Daun Kremah Merah

\section{Suhu Ekstraksi} $\mathrm{pH}$

Suhu Kamar $\left(25^{\circ} \mathrm{C}\right)$

3,1892

Suhu Dingin $\left(8^{\circ} \mathrm{C}\right)$ 3,0392

b

Keterangan : Angka-angka pada lajur yang sama yang diikuti oleh huruf kecil yang sama menunjukkan berbeda tidak nyata pada taraf $5 \%$.

Tabel 9. Pengaruh Konsentrasi Asam Sitrat Terhadap pH Ekstrak Bubuk Pigmen Betacyanin dari Daun Kremah Merah

\begin{tabular}{lcc}
\hline Konsentrasi Asam & pH & \\
\hline $0 \%$ & 5,6917 & \\
$1 \%$ & 2,7200 & \\
$3 \%$ & 2,1733 & \multicolumn{2}{c}{} \\
$5 \%$ & 1,8717 & d \\
\hline
\end{tabular}

Keterangan : Angka-angka pada lajur yang sama yang diikuti oleh huruf kecil yang sama menunjukkan berbeda tidak nyata pada taraf $5 \%$.

Tabel 10. Pengaruh Interaksi antara Suhu Ekstraksi dan Konsentrasi Asam Sitrat Terhadap pH Ekstrak Bubuk Pigmen Betacyanin Daun Kremah Merah

\begin{tabular}{lccc}
\hline \multicolumn{1}{c}{ Suhu Ekstraksi } & $\begin{array}{c}\text { Konsentrasi } \\
\text { Asam }\end{array}$ & \multicolumn{1}{c}{ pH } \\
\hline SuhuKamar $\left(25^{\circ} \mathrm{C}\right)$ & $0 \%$ & $5,8467 \mathrm{a}$ & \\
Suhu Dingin $\left(8^{\circ} \mathrm{C}\right)$ & $0 \%$ & $5,5367 \mathrm{~b}$ & \\
Suhu Kamar $\left(25^{\circ} \mathrm{C}\right)$ & $1 \%$ & 2,7667 & $\mathrm{C}$ \\
Suhu Dingin $\left(8^{\circ} \mathrm{C}\right)$ & $1 \%$ & 2,6733 & $\mathrm{C}$ \\
Suhu Kamar $\left(25^{\circ} \mathrm{C}\right)$ & $3 \%$ & 2,2500 & $\mathrm{~d}$ \\
Suhu Dingin $\left(8^{\circ} \mathrm{C}\right)$ & $3 \%$ & 2,0967 & $\mathrm{~d}$ \\
Suhu Kamar $\left(25^{\circ} \mathrm{C}\right)$ & $5 \%$ & 1,8933 & $\mathrm{e}$ \\
Suhu Dingin $\left(8^{\circ} \mathrm{C}\right)$ & $5 \%$ & 1,8500 & $\mathrm{e}$ \\
\hline
\end{tabular}

Keterangan : Angka-angka pada lajur yang sama yang diikuti oleh huruf kecil yang sama menunjukkan berbeda tidak nyata pada taraf $5 \%$.

\section{Total Asam}

Tingginya total asam yang didapatkan disebabkan karena semakin banyaknya asam sitrat yang ditambahkan sewaktu maserasi. Menurut Anonim (2011) keasaman asam sitrat disebabkan karena adanya tiga gugus karboksil $\mathrm{COOH}$ yang dapat melepaskan proton ke dalam larutan. Jika hal ini terjadi, 
ion yang dihasilkan disebut ion sitrat. Sukardjo (1997) cit Saati (2010) menambahkan bahwa apabila konsentrasi ion $\mathrm{H}+$ lebih besar dari pada ion $\mathrm{OH}$ - maka larutan akan bersifat asam dan apabila konsentrasi ion $\mathrm{H}+$ lebih kecil dari pada ion $\mathrm{OH}-$ maka larutan akan bersifat basa. Menurut Anonim (2011) asam sitrat aman digunakan dalam bahan pangan walaupun dalam jumlah besar karena asam sitrat bisa dimetabolisme dan dikeluarkan dari tubuh. Pengaruh Suhu Ekstraksi, Konsentrasi Asam Sitrat, serta Interaksi antara Suhu Ekstraksi dan Konsentrasi Asam Sitrat Terhadap Total Asam Ekstrak Bubuk Pigmen Betacyanin dari Daun Kremah Merah masing-masing dapat dilihat pada Tabel 11, Tabel 12, dan Tabel 13.

Tabel 11. Pengaruh Suhu Ekstraksi Terhadap Total Asam Ekstrak Bubuk Pigmen Betacyanin dari Daun Kremah Merah

\begin{tabular}{lc}
\hline Suhu Ekstraksi & Total Asam (\%) \\
\hline Suhu Kamar $\left(25^{\circ} \mathrm{C}\right)$ & 20,173 \\
Suhu Dingin $\left(8^{\circ} \mathrm{C}\right)$ & 20,011 \\
\hline
\end{tabular}

Tabel 12. Pengaruh Konsentrasi Asam Sitrat Terhadap Total Asam Ekstrak Bubuk Pigmen Betacyanin dari Daun Kremah Merah

\begin{tabular}{lcc}
\hline Konsentrasi Asam & Total Asam (\%) \\
\hline $5 \%$ & $43,126 \mathrm{ar}$ & \\
$3 \%$ & $26,218 \quad \mathrm{~b}$ & \\
$1 \%$ & 9,352 & $\mathrm{C}$ \\
$0 \%$ & 1,674 & $\mathrm{~d}$ \\
\hline
\end{tabular}

Keterangan : Angka-angka pada lajur yang sama yang diikuti oleh huruf kecil yang sama menunjukkan berbeda tidak nyata pada taraf $5 \%$.

Tabel 13. Pengaruh Interaksi antara Suhu Ekstraksi dan Konsentrasi Asam Sitrat Terhadap Total Asam Ekstrak Bubuk Pigmen Betacyanin Daun Kremah Merah

\begin{tabular}{lcll}
\hline Suhu Ekstraksi & $\begin{array}{c}\text { Konsentrasi } \\
\text { Asam }\end{array}$ & $\begin{array}{l}\text { Total Asam } \\
(\%)\end{array}$ \\
\hline SuhuKamar $\left(25^{\circ} \mathrm{C}\right)$ & $5 \%$ & $43,979 \mathrm{a}$ & \\
Suhu Dingin $\left(8^{\circ} \mathrm{C}\right)$ & $5 \%$ & 42,272 & $\mathrm{a}$ \\
Suhu Kamar $\left(25^{\circ} \mathrm{C}\right)$ & $3 \%$ & 26,442 & $\mathrm{~b}$ \\
Suhu Dingin $\left(8^{\circ} \mathrm{C}\right)$ & $3 \%$ & 25,995 & $\mathrm{~b}$ \\
Suhu Dingin $\left(8^{\circ} \mathrm{C}\right)$ & $1 \%$ & 9,704 & $\mathrm{C}$ \\
Suhu Kamar $\left(25^{\circ} \mathrm{C}\right)$ & $1 \%$ & 9,001 & $\mathrm{C}$ \\
Suhu Dingin $\left(8^{\circ} \mathrm{C}\right)$ & $0 \%$ & 2,075 & $\mathrm{~d}$ \\
Suhu Kamar $\left(25^{\circ} \mathrm{C}\right)$ & $0 \%$ & 1,272 & $\mathrm{~d}$ \\
\hline \multicolumn{2}{l}{ Keterangan : Angka-angka pada lajur yang sama yang }
\end{tabular}

Keterangan : Angka-angka pada lajur yang sama yang diikuti oleh huruf kecil yang sama menunjukkan berbeda tidak nyata pada taraf $5 \%$.

\section{Aplikasi Bubuk Pigmen Betacyanin Pada Pangan Jelly}

Berdasarkan hasil penilaian uji organoleptik terhadap jelly tersebut (Tabel 14), dapat disimpulkan bahwa jelly yang mendapat nilai terbaik adalah jelly dengan konsentrasi penambahan ekstrak bubuk pigmen betacyanin sebesar 1,5 \%. Penilaiannnya meliputi suka terhadap warna, biasa untuk aroma dan suka terhadap rasa jelly. Dari pengujian organoleptik ini dapat ditarik kesimpulan bahwa ekstrak bubuk pigmen betacyanin daun kremah merah dapat diaplikasikan pada produk jelly karena dapat diterima secara organoleptik oleh paneilis.

Tabel 14. Tingkat

Penerimaan PanelisTerhadap Jelly dengan PenambahanBubuk Pigmen betacyanin dari Daun Kremah Merah.

\begin{tabular}{|c|c|c|c|}
\hline \multirow[t]{2}{*}{ Perlakuan } & \multicolumn{3}{|c|}{ Nilai Kesukaan } \\
\hline & Warna & Aroma & Rasa \\
\hline $\begin{array}{l}\text { Penambahan } \\
\text { bubuk pigmen } 0,5 \\
\%\end{array}$ & $3,32 a$ & 3,48 & 3,8 \\
\hline $\begin{array}{l}\text { Penambahan } \\
\text { bubuk pigmen } 1 \\
\%\end{array}$ & $3,76 a$ & 3,56 & 4,0 \\
\hline $\begin{array}{l}\text { Penambahan } \\
\text { bubuk pigmen } 1,5 \\
\%\end{array}$ & $4,52 \mathrm{~b}$ & 3,68 & 4,16 \\
\hline $\begin{array}{l}\text { Keterangan : } 1^{`}=\text { sanga } \\
\text { biasa, } 4=\text { suka, } 5=\text { san } \\
\text { Angka-angka pada lajur } \\
\text { kecil yang sama menun } \\
\text { taraf } 5 \% \text {. }\end{array}$ & tidal & & \\
\hline
\end{tabular}

\section{Sirup}

Berdasarkan hasil penilaian uji organoleptik terhadap sirup tersebut (Tabel 15), dapat disimpulkan bahwa sirup yang mendapat nilai terbaik adalah sirup dengan konsentrasi penambahan ekstrak bubuk pigmen betacyanin sebesar 1,5 \%. Penilaiannnya meliputi biasa sampai suka terhadap warna, biasa untuk aroma dan biasa terhadap rasa sirup. Dari pengujian organoleptik ini dapat ditarik kesimpulan bahwa ekstrak bubuk pigmen betacyanin daun kremah merah dapat diaplikasikan pada produk sirup karena dapat diterima oleh panelis secara organoleptik. 
Tabel 15. Tingkat

Penerimaan

PanelisTerhadap Sirup dengan PenambahanBubuk Pigmen betacyanin Daun KremahMerah.

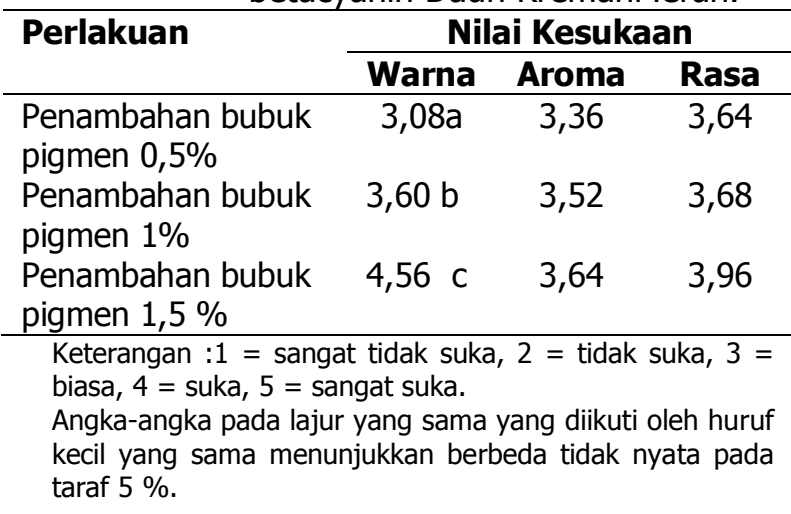

\section{Es Krim}

Berdasarkan hasil penilaian uji organoleptik terhadap es krim tersebut, dapat disimpulkan bahwa es krim yang mendapat nilai terbaik adalah es krim dengan konsentrasi penambahan ekstrak bubuk pigmen betacyanin sebesar 1,5\%. Penilaiannnya meliputi biasa sampai suka terhadap warna, biasa untuk aroma dan suka terhadap rasa es krim. Dari pengujian organoleptik ini dapat ditarik kesimpulan bahwa ekstrak bubuk pigmen betacyanin daun kremah merah dapat diaplikasikan pada produk es krim karena dapat diterima oleh panelis secara organoleptik. Tabel tingkat penerimaan panelis terhadap aplikasi ekstrak bubuk pigmen betacyanian pada es krim dapat dilihat pada Tabel 16.

Tabel 16. Tingkat Penerimaan Panelis terhadap Es Krim dengan Penambahan Ekstrak Bubuk Pigmen Betacyanin DaunKremah Merah.

\begin{tabular}{|c|c|c|c|}
\hline \multirow[t]{2}{*}{ Perlakuan } & \multicolumn{3}{|c|}{ Nilai Kesukaan } \\
\hline & Warna & Aroma & Rasa \\
\hline $\begin{array}{l}\text { Penambahan } \\
\text { bubuk pigmen } \\
0,5 \%\end{array}$ & $3,24 a$ & $3,44 a$ & $4,12 \mathrm{a}$ \\
\hline $\begin{array}{l}\text { Penambahan } \\
\text { bubuk pigmen } 1 \\
\%\end{array}$ & $3,68 a$ & $3,60 a b$ & $4,28 a b$ \\
\hline $\begin{array}{l}\text { Penambahan } \\
\text { bubuk pigmen } \\
1,5 \%\end{array}$ & $4,56 \mathrm{~b}$ & $3,96 \mathrm{~b}$ & $4,68 b$ \\
\hline $\begin{array}{l}\text { Keterangan : } \\
1{ }^{`}=\text { sangat tidak su } \\
\text { suka, } 5=\text { sangat suk } \\
\text { Angka-angka pada la } \\
\text { kecil yang sama me } \\
\text { taraf } 5 \% .\end{array}$ & $\begin{array}{l}\text { r yang s } \\
\text { Injukkan }\end{array}$ & suka, 3 & $\begin{array}{l}\text { jiasa, } 4= \\
\text { oleh huruf } \\
\text { yata pada }\end{array}$ \\
\hline
\end{tabular}

\section{KESIMPULAN}

a. Kondisi ekstraksi yang paling baik untuk maserasi betacyanin pada daun kremah merah adalah maserasi pada suhu kamar $\left(25^{\circ} \mathrm{C}\right)$.

b. Penggunaan asam sitrat pada konsentrasi 0 \% merupakan perlakuan terbaik karena menghasilkan ekstrak bubuk pigmen betacyanin daun kremah merah dengan konsentrasi betacyanin sebesar 214,47 $\mathrm{mg} / 100 \mathrm{~g}$ bahan, $\mathrm{pH} 5,85$, total asam $1,272 \%$ dan rendemen bubuk 56,43 \%,

c. Aplikasi ekstrak bubuk pigmen betacyanin pada jelly, sirup dan es krim dapat diterima secara organoleptik oleh panelis baik dari segi warna, aroma maupun rasa.

\section{DAFTAR PUSTAKA}

Anonim. 2011. Asam Sitrat. http://www.wikipedia.org [2 Mei 2011].

Azeredo, Henriette MC. 2009. Betalains: Properties, Sources, Applications and Stability. International Journal of Food Science and Technology $44: 2365-2376$.

Fardiaz S. 1992. Mikrobiologi Pangan I. Gramedia Pustaka Utama, Jakarta.

Jackman RL dan Smith JL. 1996. Anthocyanin and Betalain. Didalam Hendry GAP dan Houghton JD (eds). Natural Food Colorants, Second Edition. Capman and Hall. London.

Khuluq AD, Widjanarko SB, dan Murtini ES. 2007. Ekstraksi dan stabilitas betasianin daun darah (A/ternanthera dentata) (Kajian perbandingan pelarut air:etanol dan suhu ekstraksi). J Teknologi Pertanian 8 (3): $169-178$.

Mastuti R. 2010. Pigmen Betalain pada Famili Amaranthaceae. Basic Science Seminar VII, 20 Februari 2010, FMIPA UB. Malang.

Reid MS, Paul JL and Young RE. 1980. Effect of $\mathrm{pH}$ and Ethepon on Betacyanin Leakage from Beet Root Discs. Plant Physiol 66: 1015-1016.

Saati E. 2010. Identifikasi dan uji kualitas pigmen antosianin pada kulit buah nagamerah.http://id.shvoong.com/ta gs/[20 Mei 2011]. 
Versi Online:

http://profood.unram.ac.id/index.php/profood
Pro Food (Jurnal IImu dan Teknologi Pangan)

Vol 3 No. 1 Mei 2017

ISSN online: 2443-3446

Winarno, F.G. 2002. Kimia Gizi dan Pangan.

Gramedia Pustaka Utama, Jakarta. 